\title{
Identification of Uncertainty Factors in the Consumer Behaviour of the New Generation of Customers at the E-commerce Level
}

\author{
Jakub Horvath \\ Faculty of Management, University of Prešov, Prešov, Slovakia \\ Beata Gavurova \\ Faculty of Mining, Ecology, Process Control and Geotechnologies, Technical University of Košice, Slovakia \\ Radovan Bacik \\ Faculty of Management, University of Prešov, Prešov, Slovakia \\ Richard Fedorko \\ Faculty of Management, University of Prešov, Prešov, Slovakia
}

Received: 1 April 2021. Revision received: 2 May 2021. Accepted: 1 June 2021

\begin{abstract}
Even though two decades have passed since the introduction of e-commerce in the $\mathrm{B} 2 \mathrm{C}$ model, the uncertainty posed by the online environment makes many consumers reluctant to engage in online commerce. The buyer's behaviour is inherently uncertain, given that the buyer's decisions have consequences that cannot be fully predicted. In the relationship between the buyer and the seller, the perceived uncertainty is defined as the extent to which the buyer cannot accurately predict the outcome of the transaction due to factors related to the seller and the product. This paper deals with the uncertainty of the new generation of customers in the process of electronic commerce. Based on the analysis of previous research in the field of perception of and understanding of uncertainty in online transactions, the aim of this paper is to identify the sources of perceived uncertainty of Generation Y when shopping online. Research in this area was carried out using the method of the main components, based on which five factors related to uncertainty and concerns in the process of electronic commerce were extracted. The paper identifies the main factors of uncertainty perceived by customers and also verifies the correlation between these factors and the intention of the Millennials to buy. The subject matter is relevant and applicable both to the area of products but also to the area of services in the field of tourism and hospitality.
\end{abstract}

Key Words: e-business, e-commerce, e-shop, consumer behaviour, new generation of customers, uncertainty.

JEL Classification: M31, M37

Reference: Horvath, J., Gavurova, B., Bacik, R. \& Fedorko, R. (2021). Identification of Uncertainty Factors in the Consumer Behaviour of the New Generation of Customers at the E-commerce Level. Journal of Tourism and Services, 22(12), 168-183. doi: 10.29036/jots.v12i22.263

\section{Introduction}

Buyer behavior is inherently uncertain, given that a buyer's decisions have consequences that cannot be perfectly predicted. Uncertainty refers to the degree to which the future states of the environment cannot be accurately anticipated or predicted due to imperfect information. In buyer-seller relationships, perceived uncertainty is defined as the degree to which the buyer cannot accurately predict the outcome of a transaction due to seller and product-related factors (Németh \& Zsótér, 2019). 


\section{JOURNAL OF TOURISM AND SERVICES}

Issue 22, volume 12, ISSN 1804-5650 (Online)

www.jots.cz

Uncertainty consists of seller quality uncertainty and product quality uncertainty. Given that both aspects of uncertainty are closely interrelated and jointly describe the extent by which the outcome of a transaction can be accurately predicted, we focus on the overall degree of perceived uncertainty that incorporates the aggregate perceptions of the seller and product quality uncertainty (Kovács, 2020). Even if it may be possible to objectively capture the true degree of uncertainty in online transactions, such scientific assessment may not reflect the buyer's subjective view of transaction uncertainty that would essentially drive a buyer's future purchase intentions and actual purchases (Pavlou et al., 2007, p. 107).

All transactions have a degree of uncertainty about their outcome, and buyers cannot accurately predict whether a transaction will be fulfilled successfully. Successful fulfillment typically suggests that a seller delivers a product identical to the one promised, does so in a timely manner, and honours refund and product guarantees (Mura, 2020). In contrast, there are numerous possibilities that a transaction may not be fulfilled successfully due to seller or product quality uncertainty. For example, sellers can collect the payment but not deliver a product, deliver a product that differs from the one advertised refuse to accept payment and send a product, prolong product delivery, fail to acknowledge return, refund, and product guarantee policies, sell the buyer's private information, or not protect the buyer's monetary information, among others. Due to these numerous adverse possibilities, buyers are rightfully concerned about the "downsides" of an online transaction (Pavlou et al., 2007, p. 108).

\section{Literature review}

E-commerce has seen significant growth thanks to the development of ICT technologies. A key factor in the growth of e-commerce is the fact that the percentage of people who are in regular contact with ICT technologies is constantly increasing (Janouch, 2014). E-commerce plays an important role in today's world of commerce (Lampropoulos et al., 2019; Păunescu \& Moraru, 2018, Popesko et al., 2016). Many customers shop online. The boom in e-commerce came mainly because today's consumers use the Internet on a daily basis, they like to try new things, brands and products, but they are also modern, demanding and convenience-oriented (Rozsa \& Machova, 2020). The decisive criterion in this regard is access to the Internet, which is no longer a problem at present, as people can now connect to the Internet anytime and anywhere (Gerrikagoitia, 2015; Karacsony et al., 2020). E-commerce offers huge potential for online sales, but it also means high risks for consumers and retailers, e.g. cybercrime, hacker attacks, spam or lack of personal interactions and information asymmetry (Chatterjee \& Datta, 2008; Oluwafemi \& Adebiyi, 2018). These risks can lead to consumer uncertainty (Goker \& Ayar, 2020). This means that consumers feel insecure when buying products online as opposed to buying the same product in brickand-mortar stores (Pavlou et al., 2007). This uncertainty in online stores discourages many consumers from participating in online transactions (Almeida et al., 2019). Uncertainty has been widely promoted as a major barrier for consumers to buy products online (Pavlou et al., 2007; Gozgor \& Demir, 2018; Ključnikov et al., 2019). The Wall Street Journal (Kesmodel, 2006) also states that only $25 \%$ of consumers who searched for products online actually bought them online. Another survey showed that $65 \%$ percent of online consumers did not complete their purchase due to feelings of uncertainty about the credibility of the seller or the information on the website or presentation of the products they sell (Ključnikov et al., 2020; Ungerman et al., 2018). This earlier research shows that consumers remain to some extent insecure about e-commerce transactions. It also entails that managing this uncertainty is a key issue for e-commerce managers (Svatosova, 2020). In addition, previous research discusses some issues of uncertainty based on the fact that the consumer is unable to fully observe the seller's performance: adverse selection (hidden information) and moral hazard (hidden conduct) (Pavlou et al., 2007). This means that perceived consumer uncertainty stems from perceived information asymmetries due to hidden information and moral hazard problems. Perceived information asymmetry is defined as "the perception of the buyer that the seller has a greater amount or quality of information about his products, 


\section{JOURNAL OF TOURISM AND SERVICES}

Issue 22, volume 12, ISSN 1804-5650 (Online)

www.jots.cz

properties and sales practices" (Pavlou et al., 2007, p. 112). For example, it is difficult for an online buyer to find out if the seller is of high or low quality (seller quality or product quality) because low quality sellers may try to distort their true quality, while in brick-and-mortar stores, buyers can check it at the time of purchase (Tovmasyan, 2020). Therefore, due to the physical separation of buyers and sellers in e-commerce, the problem of information asymmetry arises, thus increasing the feelings of insecurity in online consumers (Huston \& Spencer, 2002; Ferencakova et al., 2020). Therefore, perceived information asymmetries lead to increased consumer uncertainty in the online environment (Dokulil et al., 2020). The task of online retailers must is to reduce this uncertainty.

\section{Methods}

Based on the analysis of the current state of consumer behaviour of the new generation of customers, the aim of this paper is to identify the sources of perceived uncertainty of this generation when shopping online. To achieve this, the internal factor structure of the purchasing behaviour in conditions of uncertainty will be assessed. Subsequently, a difference analysis will be performed, which will point out the differences of the identification variables of the new generation of customers in selected elements of consumer behaviour. In relation to the main objective of this paper, the following subobjectives of the research have been formulated:

- verify the proposed methodology for examining uncertainty in online shopping,

- examine the existence of links within the specified factors influencing uncertainty in online shopping,

- verify the correlation between selected factors of uncertainty in online shopping,

- verify the relationship between the intention to buy online and selected factors of uncertainty in online shopping.

The paper focuses on the consumer behaviour of Millennials and their perception of uncertainty when shopping online. Based on the main research goal and sub-goals, the following research problems were identified:

- Do selected elements of uncertainty in online shopping have an internal factor structure (Appendix A)?

- Are there statistically significant correlations between the intention to buy online and selected factors of uncertainty in online shopping?

Based on the above research problems, the following hypotheses were formulated:

H1: We assume that there is a factor structure in the selected elements related to uncertainty in online shopping (Structure, Appendix A).

H2: We assume that there are statistically significant relationships between the intention to buy online and selected factors of uncertainty in online shopping.

Primary data were obtained using a questionnaire. The link to the electronic questionnaire was placed on the relevant Facebook pages, it was also evenly distributed among the regions of the Slovak Republic by e-mail (the author's private database). A total of 962 respondents filled in the questionnaire. However, the research focuses only on the new generation of customers, - Generation Y (1984 - 2000), i.e., respondents from 20 to 36 years inclusive (Young, 2017). After removing unfit questionnaires, a total sample of 824 respondents was used. The obtained data were processed using Microsoft Excel. The results of individual analyses were obtained through Gretl and Statistica 13. The results are presented in tables and figures.

The following methods were used:

- methods of inductive statistics 


\section{JOURNAL OF TOURISM AND SERVICES}

Issue 22, volume 12, ISSN 1804-5650 (Online)

www.jots.cz

- correlation analysis (Pearson correlation coefficient, Spearman correlation coefficient),

O difference analysis (Man-Whitney U test, Friedman ANOVA),

o factor analysis (principal components method, normalized varimax rotation).

The questionnaire consisted of 30 questions, of which the first five questions aimed at classifying the analysed sample for subsequent statistical analysis. The questionnaire focused on demographic information and data related to the consumer behavior of Millennials and their perception of uncertainty when shopping online.

Furthermore, the attitudes and opinions of respondents on seven factors of consumer behavior were surveyed using a standardized structure (Appendix A). The results were used in the main components method and the subsequent factor analysis:

- intention to execute the transaction (Ajzen, 1991),

- perceived uncertainty (Torkzadeh \& Dhillon, 2002),

- purchase involvement (Laurent \& Kapferer, 1985),

- concerns about the seller's opportunism (Gundlach et al., 1995; Jap \& Anderson, 2003),

- perceived information asymmetry (Dunk 1993; Mishra et al., 1998),

- information on personal data protection (Salisbury et al., 2001; Smith et al., 1996),

- information security concerns (Salisbury et al., 2001; Yang \& Jun, 2002).

The questionnaire consisted of closed questions using the Lickert scale. The respondents were able to express the degree of agreement or disagreement with the statement through a seven-point scale. Data collection took place during the months of September to October 2020.

The research focused on a new generation of customers - Millennials (Generation Y). Regarding classification of the age group, the paper follows the methodology of Young (2017) from the company Ogilvy \& Mather. Millennials are referred to as "Generation Y" and are aged 20-36 years (Egerova et al., 2021).

Table 1. Age distribution of consumers by generation

\begin{tabular}{|c|c|}
\hline C & Centennials (2001-2009) \\
\hline Y & Millennials (1984-2000) \\
\hline X & Generation X (1964-1983) \\
\hline S & Generation S (1963 and earlier) \\
\hline
\end{tabular}

Source: own processing according to Young, 2017

The research sample consisted of 824 respondents, of which 180 (21.84\%) were men and 644 $(78.16 \%)$ were women. The average age for the whole sample was 24.73 years, for men it was 25.01 years and for women 24.64 years. The reason for this disparity is the fact that women respond more frequently than men. Given that the selection was based on availability and voluntariness, the disparity was not "corrected ". 


\section{JOURNAL OF TOURISM AND SERVICE}

Issue 22, volume 12, ISSN 1804-5650 (Online)

$$
\text { www.jots.cz }
$$

\section{Taxonomy of the factor structure of uncertainty in online shopping}

The source data for the factor analysis consists of 22 observed variables and $\mathrm{N}=824$ observed cases (respondents). The estimation of the factors of the factor model is based on the selection correlation matrix, which is given in Table 2. As some variables strongly correlate with each other (cells marked in shades of green), the factor model is plausible.

Table 2. Selection correlation matrix

\begin{tabular}{|c|c|c|c|c|c|c|c|c|c|c|c|c|c|c|c|c|c|c|c|c|c|c|}
\hline & O9 & 10 & 11 & 12 & 13 & 14 & 15 & 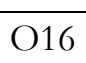 & 7 & 8 & 19 & 20 & O21 & 22 & 23 & 24 & 25 & 26 & 27 & 28 & 29 & \\
\hline O9 & 1 & & & & & & & & & & .1 & .1 & & 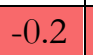 & & & .3 & 3 & 0.2 & 32 & 2 & \\
\hline 0 & 4 & 1 & & & & & & & & & & & 12 & & 27 & 39 & 37 & 31 & 25 & .3 & & \\
\hline & .5 & & 1 & & 0 & & .4 & & & & 0.2 & U. & 0.1 & .28 & .26 & 38 & 37 & 4 & 23 & -0.3 & & \\
\hline & 3 & & & & & & & & & & 0.27 & & & & & & 37 & 34 & 29 & 0.3 & 31 & \\
\hline 3 & 39 & & & -0.2 & 1 & 5 & .1 & .1 & .2 & .1 & 0 & 0 & & -0.1 & .1 & .2 & 0.2 & .1 & .1 & 0.2 & .2 & \\
\hline 14 & 2 & 16 & & & -0 & 1 & & & 13 & & 0.1 & 0.04 & 0.04 & 0.09 & 09 & 08 & 09 & 11 & 11 & -0.1 & .1 & \\
\hline & 3 & & & & & & & & & & & & & & & & & & & 0.2 & & U. \\
\hline 16 & .2 & 35 & & 6 & -0.1 & 0.1 & 55 & 1 & .63 & 67 & 32 & 21 & 0.31 & 0.29 & .25 & .32 & .32 & 38 & 34 & 0.2 & 23 & \\
\hline 17 & .3 & 35 & 39 & 39 & -0.2 & 13 & 61 & 63 & 1 & 0.65 & 0.25 & 0.23 & 0.2 & 0.25 & 0.25 & 0.33 & .31 & .36 & .32 & -0.2 & 24 & -0.2 \\
\hline 18 & .2 & & & & -0.1 & & & & & & & & 0.26 & .27 & & & 1 & & Ji & 0.2 & .2 & ). \\
\hline 19 & 0.1 & 18 & & .27 & 0 & 0.1 & 27 & 32 & 25 & 31 & 1 & 0.42 & 0.58 & 0.23 & 0.21 & 2 & .22 & .22 & 26 & -0.1 & 15 & -0.1 \\
\hline 20 & 0.1 & 22 & 21 & 21 & 0 & 04 & 31 & 21 & 23 & 0.28 & 0.42 & 1 & 0.42 & 0.28 & 0.22 & 24 & 0.22 & 21 & 0.25 & -0.1 & 0.15 & -0 \\
\hline 21 & 01 & & & & 0 & & 24 & & .2 & 0.26 & 0.58 & .4 & & 0.2 & 0.17 & .13 & .17 & 0.17 & 0.27 & -0.1 & 12 & 0. \\
\hline 22 & 0.2 & 27 & 28 & 29 & .1 & 99 & 28 & 29 & 0.25 & 0.27 & 0.23 & 0.28 & 0.21 & 1 & 0.59 & 0.61 & 0.62 & .56 & .51 & -0.3 & 35 & -0.3 \\
\hline 23 & $\overline{0.2}$ & 27 & & 27 & -0.1 & & 31 & & 25 & 0.27 & 0.21 & 0.22 & 0.1 & 0. & & 0.66 & 0.62 & 53 & .48 & 0.3 & 37 & -0.3 \\
\hline 24 & 0.3 & 0 & & & 0.2 & & 38 & & 0.33 & 0.3 & 0.2 & 0.2 & 0.13 & 0.61 & 0.6 & & 0.78 & 0.64 & 9.48 & -0.4 & .47 & -0.3 \\
\hline 25 & 0.3 & 37 & & 37 & -0.2 & & 35 & & 31 & 31 & 0.22 & 0.22 & 0.17 & 0.62 & .62 & 78 & 1 & .73 & 0.57 & -0.4 & .44 & -0.3 \\
\hline 526 & -0.3 & 31 & & 34 & -0.1 & & 12 & & & 0. & 0.2 & 0.21 & 0. & 0. & 0.5 & 64 & 0.13 & & 0.67 & -0.3 & 0.36 & -0.3 \\
\hline 27 & 0.2 & 0.25 & & & & & & & 32 & 0.3 & 0.26 & 0.25 & 0.27 & 0.51 & 0.48 & 0.48 & 0.57 & 0.67 & 1 & -0.3 & .29 & -0. \\
\hline 228 & 32 & 0.3 & 0.3 & $\overline{23}$ & $\overline{0^{\prime}}$ & -0.1 & 2 & .2 & -0.2 & -0.2 & -0.1 & -0.1 & -0.1 & -0.3 & -0.3 & -0.4 & -0.4 & -0.3 & -0.3 & 1 & -0.3 & 0.4 \\
\hline 529 & 0.2 & 0.34 & 34 & 31 & -0.2 & 0.1 & 0.24 & 23 & 0.24 & 0.2 & 0.15 & 0.15 & 0.12 & 0.35 & 0.37 & 0.47 & 0.44 & 0.36 & 0.29 & -0.3 & 1 & -0.2 \\
\hline 30 & 27 & & & & & 0 & & & & & & & & & & & & & 0 & & -0.2 & \\
\hline
\end{tabular}

Source: own processing 


\section{JOURNAL OF TOURISM AND SERVICES}

Issue 22, volume 12, ISSN 1804-5650 (Online)

www.jots.cz

The table above shows the individual correlations between the factors, which are shown based on the following spectrum from green (strong correlation) - yellow - orange - up to red (weak or no correlation).

To estimate the parameters of the factor analysis, the principal components method was used. Based on the eigenvalues of the correlation matrix and using the Kaiser's criterion, there are 6 common factors (Table 3). As for the breaking point, 5 or 6 common factors can be considered. It is also possible to decide according to the rule that 1 specific factor should contain at least 3 items. When considering 6 factors, the last 2 factors contained only 2 variables. When considering 5 factors, only 1 factor contained 2 variables. After considering all possible solutions, 5 common factors were used.

Table 3. Eigenvalues of the correlation matrix

\begin{tabular}{|l|r|r|r|r|}
\hline \multirow{2}{*}{ Value } & \multicolumn{5}{|l|}{$\begin{array}{l}\text { Eigenvalues } \\
\text { Extraction: The main components method }\end{array}$} \\
\cline { 2 - 5 } & Eigenvalue & \% total variance & Cumulative eigenvalue & Cumulative \% \\
\hline 1 & 7.3589 & 33.4496 & 7.3589 & 33.4496 \\
\hline 2 & 2.0987 & 9.5397 & 9.4576 & 42.9892 \\
\hline 3 & 1.9097 & 8.6803 & 11.3673 & 51.6695 \\
\hline 4 & 1.3281 & 6.0368 & 12.6954 & 57.7063 \\
\hline 5 & 1.1719 & 5.3269 & 13.8673 & 63.0332 \\
\hline 6 & 1.0724 & 4.8747 & 14.9398 & 67.9080 \\
\hline
\end{tabular}

In the following Table 4, the calculation of factor loads for 5 common factors continues, with the normalized varimax rotation being applied. Estimates of factor loads with values higher than 0.44 are marked in red. After rotation, the first factor accounts for 4.1976 total variance, which for 19 variables considered represents $19.08 \%$, the second factor accounts for 3.3300 total variance, which represents $15.14 \%$, and so on. The estimation based on the principal components method explains $63.01 \%$ of the variability contained in the data set. 


\section{JOURNAL OF TOURISM AND SERVICES}

Issue 22, volume 12, ISSN 1804-5650 (Online)

www.jots.cz

Table 4. Calculation of factor loads

\begin{tabular}{|c|c|c|c|c|c|}
\hline \multirow[t]{2}{*}{ Variable } & \multicolumn{5}{|c|}{$\begin{array}{l}\text { Factor loads (Varimax normalized rotation) } \\
\text { Extraction: The main components method } \\
\text { (Marked loads are }>0,44 \text { ) }\end{array}$} \\
\hline & Factor 1 & Factor 2 & Factor 3 & Factor 4 & Factor 5 \\
\hline O9 & -0.1376 & \begin{tabular}{r|}
-0.1989 \\
\end{tabular} & -0.6009 & 0.0997 & -0.3092 \\
\hline O10 & 0.1258 & 0.3485 & 0.6681 & 0.0765 & 0.1260 \\
\hline O11 & 0.1095 & 0.4093 & 0.6965 & 0.0738 & 0.0836 \\
\hline O12 & 0.1319 & 0.4711 & 0.5441 & 0.1693 & 0.0287 \\
\hline O13 & -0.0658 & -0.0303 & -0.3087 & 0.0518 & -0.7832 \\
\hline O14 & 0.0691 & 0.0694 & -0.0354 & 0.0725 & 0.8691 \\
\hline O15 & 0.2343 & 0.7398 & 0.1862 & 0.1473 & 0.0392 \\
\hline O16 & 0.1772 & 0.7914 & 0.1527 & 0.1803 & 0.0227 \\
\hline O17 & 0.1845 & 0.7940 & 0.1153 & 0.0795 & 0.1011 \\
\hline O18 & 0.2015 & 0.8013 & 0.0731 & \begin{tabular}{l|l|}
0.1758 \\
\end{tabular} & 0.0013 \\
\hline O19 & 0.1204 & 0.1695 & 0.0817 & 0.8076 & 0.0418 \\
\hline O20 & 0.1636 & 0.1615 & 0.0916 & 0.6676 & -0.0132 \\
\hline O21 & 0.0974 & 0.1324 & 0.0133 & 0.8359 & -0.0039 \\
\hline $\mathrm{O} 22$ & 0.7462 & 0.1038 & 0.1481 & 0.1751 & 0.0298 \\
\hline $\mathrm{O} 23$ & 0.7607 & 0.0877 & 0.1697 & 0.1049 & 0.0404 \\
\hline $\mathrm{O} 24$ & 0.7900 & 0.1670 & 0.2990 & 0.0335 & 0.0270 \\
\hline $\mathrm{O} 25$ & 0.8223 & 0.1669 & 0.2631 & 0.0556 & 0.0321 \\
\hline O26 & 0.7772 & 0.3019 & 0.1378 & 0.0467 & 0.0411 \\
\hline O27 & 0.6999 & 0.2665 & -0.0008 & 0.1938 & 0.0608 \\
\hline O28 & -0.3415 & 0.0304 & -0.5856 & -0.0683 & 0.0194 \\
\hline O29 & 0.4416 & 0.0975 & 0.3600 & 0.0667 & 0.1020 \\
\hline $\mathrm{O} 30$ & -0.2671 & 0.0929 & -0.5408 & -0.0748 & 0.0262 \\
\hline Expl. var. & 4.1976 & 3.3300 & 2.7702 & 2.0462 & 1.5233 \\
\hline Prp. totl & 0.1908 & 0.1514 & 0.1259 & 0.0930 & 0.0692 \\
\hline
\end{tabular}

The following Table 5 can be used to formulate the names of individual factors. The table also outlines the specific questions from the questionnaire for the respective extracted factors. The individual factors can then be named as follows:

- Factor 1 - Information on personal data protection and sensitive information (questions 22. 23. 24. 25. 26. 27.29).

- Factor 2 - Concerns about the seller's opportunism (questions 15. 16. 17. 18).

- Factor 3 - Perceived uncertainty associated with online shopping (questions 9. 10. 11. 12. 28. 30).

- Factor 4 - Perceived information asymmetry (questions 19. 20.21).

- Factor 5 - Purchase commitment (questions13.14). 


\section{JOURNAL OF TOURISM AND SERVICES}

Issue 22, volume 12, ISSN 1804-5650 (Online)

www.jots.cz

Table 5. Factor structure of the methodology used

\begin{tabular}{|c|c|c|c|c|c|}
\hline Question in the questionnaire & $\begin{array}{c}\text { Factor } \\
1\end{array}$ & \begin{tabular}{c|} 
Factor \\
2
\end{tabular} & $\begin{array}{c}\text { Factor } \\
3\end{array}$ & \begin{tabular}{c|} 
Factor \\
4
\end{tabular} & $\begin{array}{c}\text { Factor } \\
5\end{array}$ \\
\hline 9. I feel that my online purchase is safe. & & & -0.6009 & & \\
\hline 10. I feel that the uncertainty associated with online shopping is high. & & & 0.6681 & & \\
\hline 11. I am exposed to many uncertainties when shopping online. & & & 0.6965 & & \\
\hline $\begin{array}{l}\text { 12. There is a high degree of product / service uncertainty when shopping } \\
\text { online. }\end{array}$ & & 0.4711 & 0.5441 & & \\
\hline 13. Shopping online is important to me. & & & & & -0.7832 \\
\hline 14. I don't care about shopping online. & & & & & 0.8691 \\
\hline $\begin{array}{l}\text { 15. There is a chance that the seller will send me the second-hand goods } \\
\text { instead of the first quality. }\end{array}$ & & 0.7398 & & & \\
\hline 16. There is a chance that the seller will send me the damaged goods. & & 0.7914 & & & \\
\hline $\begin{array}{l}\text { 17. There is a chance that the seller will send me the goods after the expiry } \\
\text { date. }\end{array}$ & & 0.7940 & & & \\
\hline $\begin{array}{l}\text { 18. There is a chance that the seller will breach formal or informal } \\
\text { agreements in his favor. }\end{array}$ & & 0.8013 & & & \\
\hline $\begin{array}{l}\text { 19. The online seller has more information about the quality of products / } \\
\text { services than I have at my disposal. }\end{array}$ & & & & 0.8076 & \\
\hline 20. The online seller has more information about my order than I have. & & & & 0.6676 & \\
\hline $\begin{array}{l}\text { 21. An online seller has more information about the quality of his sales } \\
\text { practice than I have. }\end{array}$ & & & & 0.8359 & \\
\hline 22. I'm afraid the sellers' websites collect too much information about me. & 0.7462 & & & & \\
\hline $\begin{array}{l}\text { 23. It bothers me when they ask me for personal information on the } \\
\text { sellers' websites. }\end{array}$ & 0.7607 & & & & \\
\hline 24. When browsing the sellers' websites. I am concerned about my privacy. & 0.7900 & & & & \\
\hline 25. I have doubts about how my privacy is protected on reseller websites. & 0.8223 & & & & \\
\hline 26. My personal data could be misused when shopping on sellers' websites. & 0.7772 & & & & \\
\hline $\begin{array}{l}\text { 27. My personal data may be accessible to third parties when shopping on } \\
\text { the sellers' websites. }\end{array}$ & 0.6999 & & & & \\
\hline $\begin{array}{l}\text { 28. I feel safe in providing sensitive information when shopping on sellers' } \\
\text { websites. }\end{array}$ & & & -0.5856 & & \\
\hline $\begin{array}{l}\text { 29. The security issue of sensitive information was a major issue in my } \\
\text { online purchases. }\end{array}$ & 0.4416 & & & & \\
\hline $\begin{array}{l}\text { 30. Overall. resellers' websites are a secure place to send sensitive } \\
\text { information. }\end{array}$ & & & -0.5408 & & \\
\hline Expl. Var. & 4.1976 & 3.3300 & 2.7702 & 2.0462 & 1.5233 \\
\hline Prp. totl. & 0.1908 & 0.1514 & 0.1259 & 0.0930 & 0.0692 \\
\hline
\end{tabular}

Source: own processing 


\section{JOURNAL OF TOURISM AND SERVICES}

Issue 22, volume 12, ISSN 1804-5650 (Online)

www.jots.cz

\section{Relationships between selected factors of uncertainty in online shopping}

Based on the extracted factors. the following research problems and hypotheses are formulated:

- Problem 1a: Is there a statistically significant relationship between perceived information asymmetry (factor 4) and perceived buyer uncertainty (factor 3)?

- Hypothesis 1a: We assume that there is a significant relationship between the perceived information asymmetry (factor 4) and the perceived uncertainty of the buyer (factor 3).

- Problem 1b: Is there a statistically significant relationship between the seller's opportunism concerns (factor 2) and the buyer's perceived uncertainty (factor 3)?

- Hypothesis $1 \mathrm{~b}$ : We assume that there is a statistically significant relationship between the seller's opportunism concerns (factor 2) and the buyer's perceived uncertainty (factor 3).

- Problem 1c: Is there a statistically significant correlation between data protection concerns and the provision of sensitive information (factor 1) and perceived buyer uncertainty (factor 3)?

- Hypothesis 1c: We assume that there is a statistically significant correlation between concerns regarding the protection of personal data and the provision of sensitive information (factor 1) and the perceived uncertainty of the buyer (factor 3).

- Problem $1 \mathrm{~d}$ : Is there a statistically significant relationship between the intention to buy products online (factor 5) and the perceived uncertainty of the buyer (factor 3)?

- Hypothesis $1 \mathrm{~d}$ : We assume that there is a statistically significant relationship between the intention to buy products online (factor 5) and the perceived uncertainty of the buyer (factor 3).

The individual hypotheses 1a. 1b and 1c about the existence of statistically significant relationships were verified using Pearson's correlation coefficient. the results of which are shown in Table 15. These are the values of intercorrelation coefficients between individual extracted factors 1-5. while the relationships between individual factors are statistically significant at $\alpha=0.05$ (except for the relationship between factors 4 and 5). These coefficients also confirm the suitability of the said factor structure. The results of the coefficients that are important for verifying the established hypotheses $1 \mathrm{a}$. $1 \mathrm{~b}$ and $1 \mathrm{c}$ are highlighted in Table 6.

Table 6. Intercorrelation coefficients between extracted factors

\begin{tabular}{|c|c|c|c|c|c|}
\hline Factor & $\mathbf{1}$ & $\mathbf{2}$ & $\mathbf{3}$ & $\mathbf{4}$ & $\mathbf{5}$ \\
\hline 1 & 1.0000 & 0.4957 & $\mathbf{0 . 5 7 1 8}$ & 0.3320 & 0.1910 \\
\hline 2 & & 1.0000 & $\mathbf{0 . 5 3 0 7}$ & 0.4021 & 0.1513 \\
\hline 3 & & & 1.0000 & $\mathbf{0 . 2 6 2 7}$ & $\mathbf{0 . 3 0 8 3}$ \\
\hline 4 & & & & 1.0000 & 0.0588 \\
\hline 5 & & & & & 1.0000 \\
\hline \multicolumn{5}{|c|}{ Source: own processing } \\
\hline
\end{tabular}

Based on Table 6 above. it can be stated that factor 1 and factor 3 (0.5718) correlate the most. i.e. the attitude towards the protection of personal data and sensitive information (payment information. payment card number. etc.) is closely related to the perceived uncertainty associated with online shopping. To a large extent. factor 2 and factor 3 (0.5307) correlate - the seller's attitude to opportunism is closely linked to the perceived uncertainty associated with online shopping. Furthermore. factors 3 and 5 (0.3083) correlate the most. i.e. the perceived uncertainty in online shopping and involvement in shopping/purchase commitment. Factor 3 and factor 4 correlate the least. i.e. the perceived uncertainty in online shopping and its connection with the perceived information asymmetry in the process of electronic commerce. Correlation between factors 4 and 5 - the perceived information asymmetry and 


\section{JOURNAL OF TOURISM AND SERVICES}

Issue 22, volume 12, ISSN 1804-5650 (Online)

www.jots.cz

purchasing commitment was not confirmed. All the above correlations are in line with the studies carried out by the authors on this topic.

Based on the results of the correlation analysis. hypotheses $1 \mathrm{a} .1 \mathrm{~b} .1 \mathrm{c}$ and $1 \mathrm{~d}$ were confirmed.

The results of the factor analysis are supplemented by the assessment of the factors (identification of statistically significant differences). The null hypothesis was tested using Friedman's ANOVA (Chi Sqr. $(\mathrm{N}=824 . \mathrm{df}=4)=380.3809 ; \mathrm{p}=0.0000$ coefficient of agreement $=0.1154)$. The aim was to verify whether there are no statistically significant differences in the evaluation of individual factors. Based on the results from Table 7 . we reject this null hypothesis $(p=0.0000)$. Thus. it can be said that we have confirmed the existence of statistically significant differences in the assessment of individual factors. From the table we can see that the highest average was achieved by the factor 4 and the lowest average by the factor 5 .

Table 7. Results of Friedman ANOVA

\begin{tabular}{|l|c|r|r|r|}
\hline \multirow{2}{*}{ Variable } & \multicolumn{5}{|c|}{ Friedman ANOVA and Kendall's coefficient of agreement } \\
\cline { 2 - 5 } Factor 1 & Average ranking & Ranking sum & Average & \multicolumn{1}{c|}{ Sta. dev. } \\
\hline Factor 2 & 3.091 & 2547.0 & 4.156 & 1.309 \\
\hline Factor 3 & 2.891 & 2382.0 & 4.046 & 1.412 \\
\hline Factor 4 & 2.798 & 2305.5 & 3.982 & 0.676 \\
\hline Factor 5 & 3.831 & 3156.5 & 4.754 & 1.264 \\
\hline
\end{tabular}

Source: own processing

\section{Relationships between the intention to buy online and selected factors of uncertainty in online shopping}

The aim of the Problem 2 in the analytical part of the paper was to find out the existence of statistically significant correlations between the intention to buy online and selected factors of uncertainty in online shopping. The resulting hypothesis of the existence of statistically significant relationships was verified using Pearson's correlation coefficient. The resulting correlation matrix for the 5 tested correlations is shown in Table 8.

Table 8. Results of correlation analysis for hypothesis 2

\begin{tabular}{|c|c|c|c|}
\hline \multicolumn{4}{|c|}{ Variable 1: Question 8} \\
\hline Variable 2: & $\begin{array}{c}\text { Correlation } \\
\text { coefficient }\end{array}$ & p-value & $\begin{array}{l}\text { Correlation } \\
\text { hypothesis }\end{array}$ \\
\hline Factor 1 & -0.1041 & 0.003 & confirmed \\
\hline Factor 2 & -0.1204 & 0.001 & confirmed \\
\hline Factor 3 & 0.0669 & 0.055 & rejected \\
\hline Factor 4 & 0.0254 & 0.466 & rejected \\
\hline Factor 5 & 0.1457 & 0.000 & confirmed \\
\hline
\end{tabular}

Table 8 shows some interesting facts. As uncertainty in the provision of personal data and sensitive information increases. the intention to shop online in the near future decreases $(r=-0.1041)$. Also. with high concerns about the seller's opportunism. there is a low intention to shop online in the 


\section{JOURNAL OF TOURISM AND SERVICES}

Issue 22, volume 12, ISSN 1804-5650 (Online)

www.jots.cz

near future $(\mathrm{r}=-0.1204)$. It has been confirmed that if someone intends to shop online in the near future. online shopping is important for them $(\mathrm{r}=0.1457)$.

Based on the results of the correlation analysis. we can consider Hypothesis 2: "We assume that there are statistically significant relationships between the intention to buy online and selected factors of uncertainty in online shopping," as confirmed.

\section{Discussion}

Several authors, such as Nguyen \& Khoa (2019), Frieze \& Pegden (2018), Kim \& Krishnan (2015) and Furner, Racherla \& Zhu (2012), are currently conducting research in understanding uncertainty and reducing it. Busseri, Lefcourt \& Kerton (1998), Edwards \& Weary (1998), Heath \& Tversky (1991), have also addressed this issue in the past.

The results of the paper correspond to the results of the above studies in the following key areas. First, the results confirm the significant negative impact of perceived uncertainty on purchase intentions and confirm the claim that the existence of a perception of uncertainty is a major barrier to online barter. Second, by demonstrating the impact of purchasing intentions on transactions over time, this research contributes to the emerging literature on e-commerce uncertainty, where there are few comprehensive studies. Third, the impact of perceived uncertainty on purchasing intentions is mitigated by engaging in purchasing, further emphasizing the potentially destructive impact of perceived uncertainty on purchases that are important to consumers. Fourth, if the research results are interpreted through a principal-agent perspective, they extend it and clarify the nature of perceived uncertainty in the online environment by proposing and validating a set of four predecessors of uncertainty: perceived information asymmetry, concerns about seller opportunism, privacy and information concerns., safety concerns, which together explain the significant degree of dispersion of perceived uncertainty.

The added value of the implemented research in comparison with other studies lies in the following points:

- this is the first research carried out in the given issue in the conditions of electronic trading in Slovakia,

- while other studies focus on examining the perception and understanding of uncertainty within the general population, the research carried out in the present paper focuses on a new generation of customers (Generation Y), resp. Millennials, such research is unparalleled in the world at the level of this sample,

- in addition to identifying sources of uncertainty (perceived information asymmetries, seller's opportunism concerns, privacy concerns and information security concerns), uncertainty mitigators (diagnostics or product transparency, trust, website informativeness and social presence) are proposed by analogy (Structure, Appendix A).

\section{Conclusion}

Life before the Internet is unimaginable for many Millennials. Generation Y uses the Internet in almost every aspect of their lives, whether it's looking for trusted resources to write seminar papers. Order food, watch online TV. or meet new people through cyberspace - the Internet has become an integral part of their lives. At the same time, widespread use of the Internet may not necessarily be a negative thing, it has lasting effects on the lives of Millennials. All these actions implemented in the process of e-commerce are necessarily related to uncertainty, especially concerning its understanding and subsequent reduction. The paper examined the uncertainty in the context of the quality of sellers and their products/ services. 


\section{JOURNAL OF TOURISM AND SERVICES}

Issue 22, volume 12, ISSN 1804-5650 (Online)

www.jots.cz

The issue of uncertainty in online transactions is still a relatively new and at the same time, an extensive area of knowledge, which is characterized by rapid development due to the growth of ecommerce. The paper identifies the most important factors in relation to the perceived uncertainty in online shopping through the main components method. To better understand the perception of uncertainty by the new generation of customers, standardized structure related to transaction intent purchase involvement, concerns about seller's opportunism, perceived information asymmetries, and privacy and information security concerns were used.

Based on the results of the research, it can be stated that the correlation between the perceived uncertainty of buyers and the following factors were confirmed: perceived information asymmetry concerns about seller's opportunism concerns about personal data protection and sensitive information provision purchase involvement and online shopping itself.

Significant correlations between the intention to purchase online and selected factors of uncertainty in online shopping were also confirmed. These factors were: privacy and sensitive information, concerns about the seller's opportunism, and purchase involvement.

Based on the results of the research, three factors are proposed that create a perception of uncertainty in online exchanges:

- first, the spatial and temporal separation between buyers and sellers creates an information asymmetry in favour of the seller, which leads to a perceived information asymmetry of the buyer,

- second, the discrepancy between objectives and the time lag between payment and delivery raises concerns that the product may not be what the seller promises or that sellers may abuse buyers, leading to buyer concerns about the seller's opportunism,

- the global and open Internet infrastructure allows sellers to easily collect, process, and use private and payment information about the buyer, which raises concerns about the protection of personal data and information security.

\section{Acknowledgment}

This paper is one of the partial outputs under the scientific research grant VEGA 1/0694/20 Relational marketing research - perception of e-commerce aspects and its impact on purchasing behaviour and consumer preferences and VEGA 1/0609/19 - Research on the development of electronic and mobile commerce in the aspect of the impact of modern technologies and mobile communication platforms on consumer behaviour and consumer preferences.

\section{References}

1. Ajzen. I. (1991). The Theory of Planned Behavior. Organizational Behavior and Human Decision Processes, 50, 179-211.

2. Almeida, F., Almeida, J. \& Mota, M. (2019). Perceptions and Trends of Booking Online Payments in Tourism. Journal of Tourism and Services, 10(18), 1-15.

3. Busseri, M. A., Lefcourt, H. M. \& Kerton, R. R. (1998). Locus of Control for Consumer Outcomes: Predicting the Consumer Behavior. Journal of Applied Social Psychology, 28(12). 135-144.

4. Dokulil, J., Popesko, B., \& Dvorský, J. (2020). The budgeting processes of czech companies: The role of the ownership structure and foreign capital. Oeconomia Copernicana, 11(4), 779-798.

5. Dunk. A. S. (1993). The Effect of Budget Emphasis and Information Asymmetry on the Relation Between Budgetary Participation and Slack. Accounting Review, 68(2), 400-410.

6. Edwards, J. A. \& Weary, G. (1998). Antecedents of causal uncertainty and perceived control: A prospective study. European Journal of Personality, 12, 135-148. 


\section{JOURNAL OF TOURISM AND SERVICES}

Issue 22, volume 12, ISSN 1804-5650 (Online)

www.jots.cz

7. Egerová, D., Kutlák, J., \& Eger, L. (2021). Millennial job seekers' expectations: How do companies respond? Economics and Sociology, 14(1), 46-60.

8. Ferencakova, L., Gajdka, K., Netek, V. \& Kapoun, P. (2020). Engaging Customers on Facebook Coffee Shops' Brand-Fan Pages. International Journal of Entrepreneurial Knowledge, 8(1), 65-75.

9. Frieze, A. \& Pegden, W. (2018). Online purchasing under uncertainty. Random Structures \& Algorithms. 53(2). 327-351.

10. Furner, CH., Racherla, P. \& Zhu, Z. (2012). Uncertainty, trust and purchase intention based on online product reviews: An introduction to a multinational study. International Journal of Networking and Virtual Organisations, 11(3/4), 260-276.

11. Gerrikagoitia. J. K. et al. (2015). New Trends of Intelligent E-marketing Based on Web Mining for E-shops. Procedia - Social and Behavioral Sciences, 175, 75-83.

12. Goker, G. \& Ayar, I. (2020). Intermediary Role of Nostalgia Tendency in The Effect of Electronic Word of Mouth Communication on Tourists' Destination Visit Intentions. Journal of Tourism and Services, 20(11), 44-59.

13. Gozgor, G. \& Demir, E. (2018). The Effects of Economic Policy Uncertainty on Outbound Travel Expenditures. Journal of Competitiveness, 10(3), 5-15.

14. Gundlach. G. T., Achlor. R. \& Mentzer. J. (1995). The Structure of Commitment in Exchange. Journal of Marketing, 59(1), 78-92.

15. Heath, C. \& Tversky, A. (1991). Preference and Belief: Ambiguity and Competence in Choice under Uncertainty. Journal of Risk and Uncertainty, 4, 5-28.

16. Huston. J. H. \& Spencer. R. W. (2002). Quality. Uncertainty and the Internet: The Market for Cyber Lemons. American Economist, 46(1), 50-60.

17. Chatterjee. S. \& Datta. P. (2008). Examining Inefficiencies and Consumer Uncertainty in Ecommerce. Communications of the Association for Information Systems, 22(29), 525-546.

18. Janouch. V. (2014). Internetory marketing. Brno: Computer Press.

19. Jap. S. D. \& Anderson. E. (2003). Safeguarding Interorganizational Performance and Continuity Under ex post Opportunism. Management Science, 49(12), 1684-1701.

20. Karacsony, P., Izsák, T. \& Vasa, L. (2020). Attitudes of Z generations to job searching through social media. Economics and Sociology, 13(4), 227-240.

21. Kesmodel. D. (2006). Despite Growth of E-commerce. Some Retailers Remain Offline. Wall Street Journal. 2.

22. Kim, Y. \& Krishnan, R. (2015). On Product-Level Uncertainty and Online Purchase Behavior: An Empirical Analysis. Management Science, 61(10), 2449- 2467.

23. Ključnikov, A., Civelek, M., Vozňáková, I. \& Krajč́k, V. (2020). Can discounts expand local and digital currency awareness of individuals depending on their characteristics? Oeconomia Copernicana, 11(2), 239-266.

24. Ključnikov, A., Popesko, B., \& Kloudová, J. (2019). Economics of the international ridesharing services-a trap for amateurs. Entrepreneurship and Sustainability Issues, 6(3), 1172-1181.

25. Kovács, K. (2020). Relative consumption with multiple reference points under uncertainty. Economics \& sociology, 13(4), 61-80.

26. Lampropoulos, G., Siakas, K. \& Anastasiadis, T. (2019). Internet of Things in the Context of Industry 4.0: An Overview. International Journal of Entrepreneurial Knowledge, 7(1), 4-19.

27. Laurent. G. \& Kapfere. J. (1985). Measuring Consumer Involvement Profiles. Journal of Marketing Research, 22(1), 41-53.

28. Mishra. D. P., Heide. J. B. \& Cort. S. G. (1998). Information Asymmetry and Levels of Agency Relationships. Journal of Marketing Research, 35(3), 277-295.

29. Mura, L. (2020). Marketing Management of Family Businesses: Results of Empirical Study. International Journal of Entrepreneurial Knowledge, 8(2), 56-66. 


\section{JOURNAL OF TOURISM AND SERVICES}

Issue 22, volume 12, ISSN 1804-5650 (Online)

www.jots.cz

30. Németh, E. \& Zsótér, B. (2019). Anxious spenders: Background factors of financial vulnerability. Economics and Sociology, 12(2), 147-169.

31. Nguyen, H. M. \& Khoa, B. T. (2019). The Relationship between the Perceived Mental Benefits, Online Trust, and Personal Information Disclosure in Online Shopping. Journal of Asian finance economics and business, 6(4), 261-270.

32. Oluwafemi, A. J. \& Adebiyi, S. O. (2018). Customer Loyalty and Integrated Marketing Communications among Subscribers of Telecommunication Firms in Lagos Metropolis, Nigeria. Journal of Competitiveness, 10(3), 101-118.

33. Ungerman, O., Dedkova, J. \& Gurinova, K. (2018). The impact of marketing innovation on the competitiveness of enterprises in the context of industry 4.0. Journal of Competitiveness, 10 (2), 132 148.

34. Păunescu, C. \& Moraru, R. (2018). Maximizing social value in the hotel online environment using an analytic hierarchy process. Journal of Competitiveness, 10(1), 106-124.

35. Pavlou. P. A., Liang. H. \& Xue, Y. (2007). Understanding and Mitigating Uncertainty in Online Exchange Relationships: A Principal-Agent Perspective. MIS Quarterly, 31(1), 105-136.

36. Popesko, B., Ključnikov, A., Hrabec, D., \& Dokulil, J. (2016). Predictability of business environment within budgeting process - is it connected with fluctuations of economy? Economics and Sociology, 9(2), 90-100.

37. Rozsa, Z. \& Machova, V. (2020). Factors Affecting Job Announcement Competitiveness on Job Listing Websites. Journal of Competitiveness, 12(4), 109-126.

38. Salisbury. W., Pearson. R., Pearson. A. \& Miller. D. (2001). Identifying Barriers That Keep Shoppers off the World Wide Web: Developing a Scale of Perceived Web Security. Industrial Management \& Data Systems, 101(4), 165-176.

39. Smith. H. J., Milberg. S. \& Burke. S. (1996). Information Privacy: Measuring Individuals' Concerns about Organizational Practices. MIS Quarterly, 20(2), 167-196.

40. Svatosova, V. (2020). The Importance of Online Shopping Behavior in the Strategic Management of E-Commerce Competitiveness. Journal of Competitiveness, 12(4), 143-160.

41. Torkzadeh. G. \& Dhillon. G. (2002). Measuring Factors that Influence the Success of Internet Commerce. Information Systems Research, 13(2), 187-204.

42. Tovmasyan, G. (2020). Evaluating the quality of hotel services based on tourists' perceptions and expectations: The case study of Armenia. Journal of International Studies, 13(1), 93-107.

43. Huang, W-S., Chang, Ch-T. \& Sia, W-Y. (2019). An empirical study on the consumers' willingness to insure online. Polish Journal of Management Studies, 20(1), 202-212.

44. Yang. Z. \& Jun, M. (2002). Consumer Perception of e-Service Quality: From Internet Purchaser and Non-Purchaser Perspectives. Journal of Business Strategies, 19, 19-41.

45. Young. M. (2017). Ogilvy o reklaměv digitálním věku. Bratislava: Svojtka \& Co.

\section{Brief description of Authors:}

\section{PhDr. Jakub Horvath, PhD. MBA}

ORCID ID: https://orcid.org/0000-0002-9691-7598

Faculty of management. University of Prešov

Department of management

Konštantínova 16

08001 Prešov

Slovakia

unipo.sk/fm

jakub.horvath@unipo.sk 


\section{JOURNAL OF TOURISM AND SERVICES}

Issue 22, volume 12, ISSN 1804-5650 (Online)

www.jots.cz

Jakub Horvath is an assistant professor at the Faculty of Management, University of Prešov. His main research area is new generation customer shopping behaviour online and uncertainty in online transactional relationships.

prof. Ing. Beata Gavurova, PhD. MBA

ORCID ID: https://orcid.org/0000-0002-0606-879X

Technical University of Košice, Faculty of Mining, Ecology, Process Control and Geotechnologies, Institute of Earth Resources

Letná 9

04200 Košice

Slovakia

https:// fberg.tuke.sk/wps/portal

beata.gavurova@tuke.sk

Beata Gavurova is an expert in finance, financial analysis, and financial risk management. She focuses on her research work on measurement and performance management issues in various sectors, process management, process optimization, and strategic and performance benchmarking. Her dominant research area is the development and testing in the management and performance measurement, the evaluation of methodologies, and the preparation of an application platform for innovative management and performance measurement with the support of ICT. She led several national projects, has participated in many international projects targeting the innovative applications of ICT in the private and public sectors.

doc. PhDr. Radovan Bacik, PhD. MBA. LL.M.

ORCID ID: https://orcid.org/0000-0002-5780-3838

Faculty of management. University of Prešov

Department of management

Konštantínova 16

08001 Prešov

Slovakia

unipo.sk/fm

radovan.bacik@unipo.sk

Radovan Bacik is an associate professor at the Faculty of Management, University of Prešov. His main research area is the development of electronic and mobile commerce in the aspect of the impact of modern technologies and mobile communication platforms on consumer behaviour and consumer preferences.

doc. Mgr. Richard Fedorko, PhD.

ORCID ID: https://orcid.org/0000-0003-3520-1921

Faculty of management. University of Prešov

Department of management

Konštantínova 16

08001 Prešov

Slovakia

unipo.sk/fm

richard.fedorko@unipo.sk

Richard Fedorko is an associate professor at the Faculty of Management, University of Prešov. His main research area is the perception of e-commerce aspects and their impact on purchasing behaviour and consumer preferences. 


\section{JOURNAL OF TOURISM AND SERVICES}

Issue 22, volume 12, ISSN 1804-5650 (Online)

www.jots.cz

Appendix A Intention to execute the transaction (Ajzen, 1991)

Given my needs. I intend to shop online in the near future.

Perceived Uncertainty (Torkzadeh \& Dhillon, 2002)

I feel that my online purchase involves a high degree of uncertainty.

I feel that the uncertainty associated with online shopping is high.

I am exposed to many uncertainties when shopping online.

There is a high degree of uncertainty regarding the product / service (i.e. the product / service I

Purchase involvement (Laurent \& Kapferer, 1985)

Shopping online is important to me.

I don't care about shopping online.

Concerns about seller's opportunism (Gundlach et al., 1995; Jap \& Anderson, 2003)

There is a chance that the seller will send me the second-hand goods instead of the first quality

There is a chance that the seller will send me the damaged goods.

There is a chance that the seller will send me the goods after the expiry date.

There is a chance that the seller will breach formal or informal agreements in his favor

Perceived information asymmetry (Dunk, 1993; Mishra et al., 1998)

The online seller has more information about the quality of products / services than I have at my

The online seller has more information about my order than I have.

An online seller has more information about the quality of his sales practice than I have.

Information on personal data protection (Salisbury et al., 2001; Smith et al., 1996)

I'm afraid the sellers' websites collect too much information about me.

It bothers me when they ask me for personal information on the sellers' websites.

When browsing the sellers' websites. I am concerned about my privacy.

I have doubts about how my privacy is protected on reseller websites.

My personal data could be misused when shopping on sellers' websites.

My personal data may be accessible to third parties when shopping on the sellers' websites.

Information security concerns (Salisbury et al., 2001; Yang \& Jun, 2002)

I feel secure in providing sensitive information (such as a credit card number) when making purchases

The security issue of sensitive information was a major issue in my online purchases.

Overall. resellers' websites are a secure place to send sensitive information (reverse coding). 